\section{LA LEY DE ACCIDENTES DEL TRABAJO $Y$ LOS DEBATES PROMOVIDOS PARA LA CREACIÓN DE UN FUERO LABORAL (ARGENTINA, 1904-1946)}

\author{
THE LAW OF WORK ACCIDENTS AND \\ THE DEBATES TOWARD THE CREATION OF \\ LABOUR COURT (ARGENTINA, 1904-1946) \\ ANDRÉS STAGNARO •
}

Andrés Stagnaro es becario post doctoral de CONICET y docente en la Universidad Nacional de La Plata, e investigador en el instituto de Investigaciones en

\section{Resumen}

La posibilidad de sancionar una ley que protegiese al trabajador ante un eventual accidente fue un debate central en el desarrollo de la legislación laboral. Ninguna de las leyes previas sobre derecho del trabajo implicó un cambio tan importante en la doctrina jurídica como la ley $n^{\circ} 9688$ de 1915. La inclusión en una ley de la inversión de la carga de la prueba fue un duro examen para las posibilidades del fuero civil de responder a las problemáticas devenidas de la relación entre el trabajador y su patrón y abrió las puertas para un debate sobre la posibilidad de constituir un nuevo fuero dedicado a los conflictos emergentes de la relación laboral. El artículo se propone explorar los límites de la justicia civil y las derivaciones doctrinarias de la asunción de la doctrina del riesgo profesional. Estos límites se abordan conjuntamente con los debates generados entre los especialistas de la época y, las propuestas de conformación de un nuevo fuero cuyas características procedimentales fuesen solidarias con las nuevas doctrinas.
Humanidades y Ciencias Sociales, CONICET-UNLP. e-mail: andres.stagnaro81@gmail.com

\section{Abstract}

The chance to pass a law that would protect the worker against a possible labor accident was a central debate in the development of labor law. None of this previous labour laws entailed a major change in legal doctrine, as the law $n^{\circ} 9688$ of 1915 . The inclusion in a law of the principle of reversing the burden of proof was a tough examination for the civil courts possibilities to respond to the problematic relationship between the worker and his employer, and opened the doors for a discussion on the possibility of constitute a new type of courts dedicated to the emerging conflicts between workers and employers. The article explores the limits of civil justice and the consequences of the assumption of professional risk doctrine. These limits are addressed in conjunction with the debates, by specialists, of the proposition to create a new jurisdiction whose procedural characteristics were sympathetic to the new doctrines. 